\title{
PENINGKATAN HASIL BELAJAR BIOLOGI SISWA DENGAN MENGGUNAKAN METODE BERMAIN PERAN PADA MATERI SISTEM PEREDARAN DARAH MANUSIA
}

\author{
Kolbert Pakpahan ${ }^{1}$, Julaga Situmorang ${ }^{2}$, Hasruddin ${ }^{3}$ \\ ${ }^{1}$ Sekolah Menengah Pertama Negeri 4 Doloksanggul, Sumatera Utara \\ ${ }^{2,3}$ Program Pascasarjana, Universitas Negeri Medan, Medan \\ ${ }^{1}$ kolbertpakpahan@gmail.com; ${ }^{2}$ profjulagasitumorang@gmail.com; \\ ${ }^{3}$ hasruddin_lbsmdn@yahoo.com
}

\begin{abstract}
Abstrak: Penelitian ini dilaksanakan bertujuan untuk; meningkatkan kualitas proses pembelajaran dan hasil belajar siswa pada mata pelajaran biologi kelas VIII-1 di SMP Negeri 4 Doloksanggul untuk materi sistim peredaran darah manusia. Penelitian tindakan kelas ini dilakukan di kelas VIII-1 SMP negeri 4 Doloksanggul untuk mata pelajaran biologi semester tiga. Dari penelitian yang telah dilakukan selama lima bulan pada tahun ajaran 2010/2011 ini dapat disimpulkan sebagai berikut; (1) jumlah peserta didik yang tuntas pada siklus pertama submateri komponenkomponen darah dan struktur jantung ada sebanyak 8 orang atau sebesar 27,6\%;(2) Jumlah peserta didik yang tuntas pada siklus kedua submateri skema pembekuan darah manusia dan teknik identifikasi golongan darah ada sebanyak 19 orang atau sebesar 65,52\%; (3) Terjadi peningkatan hasil belajar peserta didik pada materi sistem peredaran darah manusia kelas VIII-1 di SMP Negeri 4 Doloksanggul dari siklus pertama ke siklus kedua sebesar 37,92\%.
\end{abstract}

Kata Kunci: biologi, metode bermain peran, sistem peredaran darah manusia

Abstract: This research was carried out aimed at; improve the quality of the learning process and student learning outcomes in biology class VIII-1 in Doloksanggul 4 Middle School for human circulatory system material. This classroom action research was carried out in class VIII-1 of the 4 Doloksanggul state junior high school for third semester biology subjects. From the research that has been conducted for five months in the 2010/2011 school year this can be summarized as follows; (1) the number of students who completed the first cycle of submission of components of blood and heart structure as many as 8 people or 27.6\%; (2) the number of students who completed the second cycle of submersion of human blood clotting scheme and group identification techniques blood is 19 people or $65.52 \%$; (3) Increased learning outcomes of students in the material of the human circulatory system class VIII-1 in SMP Negeri 4 Doloksanggul from the first cycle to the second cycle of $37.92 \%$.

Keywords: biology, role playing method, human circulatory system

\section{PENDAHULUAN}

Dalam proses pembelajaran seorang guru sudah berupaya keras dalam menjelaskan mata pelajaran yang diasuhnya tetapi sering tidak dimengerti oleh peserta didik. Aktivitas mendengarkan yang dilakukan oleh peserta didik adalah aktivitas belajar dan sering terjadi dalam percakapan sehari-hari. Percakapan akan memberi situasi tersendiri bagi orang-orang yang terlibat langsung atau tidak langsung mendengar informasi. Situasi mendengarkan itu memberikan kesempatan kepada seseorang untuk belajar. Peserta didik yang mau belajar ataupun tidak dalam situasi ini tergantung ada tidaknya kebutuhan, motivasi, dan tujuan.
Dengan adanya kebutuhan, motivasi, dan tujuan memungkinkan seseorang tidak hanya mendengar, tetapi menjadi pendengar yang aktif dan bertujuan. Proses pembelajaran di sekolah yang sering terjadi adalah komunikasi verbal dari guru kepada peserta didik dan tugas peserta didik mendengarkan. Jika mendengarkan tidak didorong oleh kebutuhan, motivasi, dan tujuan dalam belajar maka hal itu merupakan pekerjaan yang sia-sia.

Keberhasilan proses pembelajaran di kelas dapat dilihat dari aktivitas belajar dan hasil belajar siswa. Berdasarkan hasil observasi awal dan diskusi dengan sesama guru biologi yang dilakukan dalam kegiatan pembelajaran di 
sekolah diperoleh bahwa hasil belajar biologi selama ini marih rendah dibandingkan dengan Kriteria Ketuntasan Minimal (KKM). Rendahnya hasil belajar tersebut akibat kurang aktifnya siswa dalam pembelajaran. Di samping itu konsep-konsep biologi secara umum sulit dipahami karena penuh dengan hafalan.

Kebanyakan dari siswa menganggap bahwa mata pelajaran biologi sebagai mata pelajaran yang membosankan, dan membutuhkan hafalan yang banyak, latihanlatihan serta kejelian dan ketelitian. Saat pelajaran biologi berlangsung sebagaian besar siswa kurang antusias atau kurang memperhatikan guru. Siswa terlihat jenuh, bahkan siswa kurang menyukai bahasa- bahasa ilmiah, dimana sebagian besar materi biologi menggunakan bahasa ilmiah. Hal ini penulis rasakan pada saat peneliti melakukan observasi. Oleh karena itu kreativitas seorang guru dalam mengajar biologi untuk memilih metode yang tepat merupakan faktor penting agar biologi menjadi mata pelajaran yang menyenangkan dan menarik bagi siswa. Dalam pengajaran diperlukan suatu metode pembelajaran yang sesuai, misalnya metode bermain peran. Mata pelajaran biologi termasuk salah satu pelajaran yang dianggap sulit, yang berdampak pada hasil belajar siswa rendah. Hal ini dapat dilihat dari nilai rata - rata ujian akhir siswa untuk pelajaran biologi masih rendah. Salah satu penyebab rendahnya nilai ujian akhir biologi adalah sikap siswa yang pasif saat proses pembelajaran berlangsung.

Berdasarkan hasil kegiatan "fieild study" diperoleh gambaran mengenai permasalahan proses belajar mengajar di SMP negeri 4 Doloksanggul yang berkaitan dengan kinerja guru di antaranya; (1) proses pembelajaran biologi belum berlangsung secara optimal di mana siswa tidak terlibat aktif di kelas; (2) umumnya guru mengajar biologi menggunakan media pembelajaran atau alat peraga yang minim; (3) penyampaian materi dalam pembelajaran biologi kebanyakan masih menekankan pada aspek kognitif; (4) kreativitas guru dalam menerapkan metode pembelajaran masih kurang, hanya melaksanakan dengan metode ceramah saja; dan (5) adanya kekhawatiran guru berkaitan dengan keterbatasan waktu yang disediakan untuk menyelesaikan materi yang harus dibahas sehingga guru banyak menggunakan metode ceramah dan mencatat.
Masalah-masalah yang ada pada sekolah hampir merata untuk semua mata pelajaran termasuk pelajaran biologi. Mata pelajaran biologi dikembangkan melalui kemampuan berpikir analitik, induktif, dan deduktif untuk menyelesaikan masalah yang berkaitan dengan peristiwa di alam sekitar. Pendidikan biologi diharapkan menjadi wahana bagi siswa untuk mempelajari dirinya sendiri dan alam sekitarnya. Setelah mempelajari biologi siswa diharapkan dapat menerapkan konsep dan prinsip biologi untuk memecahkan masalah dalam kehidupan sehari-hari melalui metode ilmiah. Namun pada kenyataannya standar kompetensi yang diharapkan dapat diperoleh siswa setelah mempelajari mata pelajaran biologi belum dapat tercapai secara optimal. Salah satu indikator yang dapat dijadikan sebagai bukti adalah masih rendahnya perolehan nilai ujian akhir siswa untuk mata pelajaran biologi.

Dari data nilai ujian semester tersebut, setelah dilakukan peninjauan materi, skor/nilai yang terendah terjadi pada materi Sistem Peredaran Darah Manusia. Bahwa soal pada materi sistem peredaran darah selalu kategori soal sukar. Siswa pada umumnya tidak dapat menjawab soal-soal yang ada kaitannya dengan sistem peredaran darah manusia.

Materi Sistem Peredaran Darah
Manusia mempelajari tentang alat pengangkutan di dalam tubuh yang melibatkan komponen - komponen darah, jantung, dan pembuluh darah. Setiap komponen darah mempunyai fungsi yang khusus serta menempuh peredaran yang tersistematis. Jantung bertindak sebagai pompa yang mendorong darah beredar di sepanjang pembuluh darah. Jantung memiliki ruang tertentu yang berfungsi sebagai pemisah darah bersih dengan darah kotor. Pembuluh darah merupakan tempat beredarnya darah menuju dan meninggalkan jantung. Pembuluh darah yang bergerak menuju jantung dan bergerak meninggalkan jantung tentunya berbeda kandungan darahnya. Darah diedarkan keseluruh tubuh melalui pembuluh darah dan kembali ke jantung melalui pembuluh darah juga. Darah yang bergerak meninggalkan jantung disebut arteri dan darah yang bergerak menuju jantung disebut pembuluh vena. Sistem yang demikian dikenal dengan sistem peredaran darah tertutup.

Permasalahan di atas perlu diupayakan pemecahannya, salah satunya dengan 
melakukan tindakan yang dapat mengubah suasana pembelajaran yang melibatkan siswa untuk lebih aktif dalam kegiatan pembelajaran, yaitu melalui pembelajaran dengan menghadapkan siswa pada objek nyata serta melibatkan siswa, dan siswa melakukan peran dari setiap konsep biologi. Dengan komposisi materi dalam sistem peredaran darah manusia maka Metode Bermain Peran sangat cocok untuk membantu siswa dapat menelaah materi dengan memerankan langsung dari setiap komponen sistem peredaran darah. Bermain peran dalam pembelajaran biologi adalah salah satu upaya menanamkan konsep kepada siswa, karena dengan bermain peran terdapat keuntungan - keuntungannya sebagai berikut; (1) Siswa lebih percaya pada kebenaran konsep yang telah diperankan sendiri; (2) Hasil belajar yang diperoleh siswa bersifat retensi (lebih lama) dan internalisasi (menyatu dalam jiwa siswa); dan (3) memperkaya pengalaman dengan hal yang bersifat objektif. Dengan demikian pembelajaran dengan bermain peran memungkinkan untuk meningkatkan pemerolehan pengetahuan sesuai dengan harapan.

\section{Hakikat Hasil Belajar Biologi}

Sebagai bagian dari Ilmu Pengetahuan Alam (IPA), biologi merupakan pengetahuan yang harus diuji kebenarannya melalui metode ilmiah. Nasution (2003) mengemukakan bahwa biologi merupakan cabang dari Ilmu Pengetahuan Alam (IPA) yang mengutamakan kemampuan siswa untuk mengamati, mendeskripsikan dan menganalisis gejala gejala alam sehingga menjadi sebuah struktur pengetahuan yang bersistem. Bidang kajian biologi berkaitan dengan fenomena kehidupan mahkluk hidup pada berbagai tingkat organisasi kehidupan dan interaksinya dengan komponen lingkungan.

Menurut Carin (1989: 2-3) menyoroti bahwa IPA merupakan sekumpulan pengetahuan yang tersusun secara sistematis, dimana dalam penerapannya secara umum terbatas pada gejala-gejala alam. Secara utuh, IPA secara keilmuan terdiri atas tiga dimensi meliputi IPA sebagai produk (sikap, konsep dan prinsip), proses (metode atau kerja ilmiah) dan sikap .Ketiga dimensi tersebut sama pentingnya dan sebagai kebulatan dalam pengembangan pendidikan IPA. Pembelajaran biologi disekolah-sekolah pada dasarnya adalah sebagai wahana untuk meningkatkan pengetahuan, ketrampilan, sikap dan nilai. Hasil belajar IPA- Biologi disekolah yang diharapkan adalah proses sains, penguasaan konsep biologi, kreativitas, kemampuan pemecahan masalah, sikap dan ketrampilan berkomunikasi. Hasil belajar siswa dapat dipengaruhi oleh pendekatan, metode, strategi, model, dan teknik yang digunakan guru dalam proses pembelajaran (Hasruddin, 2006)

Pada hakekatnya IPA dibangun atas dasar produk ilmiah, proses ilmiah, dan sikap ilmiah. Selain itu, IPA dipandang pula sebagai proses, sebagai produk, dan sebagai prosedur. (Trianto, 2010: 137). Sebagai proses diartikan semua kegiatan ilmiah untuk menyempurnakan pengetahuan tentang alam maupun untuk menemukan pengetahuan baru. Sebagai produk diartikan sebagai hasil proses, berupa pengetahuan yang diajarkan dalam sekolah atau diluar sekolah atapun bahan bacaan untuk penyebaran atau dissimilasi pengetahuan. Sebagai prosedur dimaksudkan adalah metodologi atau cara yang dipakai untuk mengetahui sesuatu yang lazim disebut metode ilmiah.

Sementara itu, menurut Laksmi Prihantoro (1986) mengatakan bahwa IPA hakekatnya merupakan suatu produk, proses, dan aplikasi, Sebagai roduk, IPA merupakan sekumpulan pengetahuan dan sekumpulan konsep dan bagan konsep. Sebagai suatu proses, IPA merupakan proses yang dipergunakan untuk mempelajari objek studi, menemukan dan mengembangkan produk-produk sains, dan sebagai aplikasi, teori-teori IPA akan melahirkan teknologi yang dapat memberi kemudahan bagi kehidupan.

Menurut Suyitno (1995: 112) agar materi pelajaran biologi mudah dipahami oleh siswa ada 3 (tiga) hal yang perlu dipahami oleh setiap guru sebagai modal utama dalam memformulasikan suatu metode pembelajaran sains, meliputi (1) Pemahaman hakekat IPA dan penguasaan materi; (2) Pemahaman terhadap karakteristik subjek belajarnya; dan (3) Pemahaman guru terhadap aspek kependidikannya. Jadi inti persoalan dalam pembelajaran biologi bukan terletak pada bagaimana guru mengajar melainkan bagaimana siswa diajak untuk belajar.

Bertitik tolak pada hakekat IPA sebagai produk dan proses dengan melihat tingkat perkembangan intelektual siswa SMP Negeri 4 Doloksanggul maka pendekatan dalam pembelajaran biologi harus dilakukan dengan 
kondusif. Seperti yang disarankan oleh Yager (1996: 5) agar proses pembelajaran IPA dapat berlangsung dalam kondisi kondusif, maka seorang guru harus: (1) Dapat menerima dan mendorong inisiatif dan gagasan siswa; (2) Dalam merancang pembelajaran, guru harus mempertimbangkan respon siswa; (3) Mendorong siswa untuk berinteraksi baik dengan teman di kelasnya maupun dengan guru; (4) Melibatkan siswa dalam kegiatan, kemudian mendorong siswa merefleksikan dalam kehidupan sehari - hari; dan (5) Mengidentifikasi pengetahuan awal siswa sebagai acuan merancang pembelajaran yang ditujukan peningkatan pemahaman terhadap materi pelajaran.

\section{Hakikat Metode Bermain peran}

Pembelajaran adalah

cara

pengorganisasian dan pengaturan informasi bagi siswa yang meliputi sejumlah elemenelemen utama serta penyampaian informasi, pemberian contoh-contoh, praktik, dan umpan balik. Pembelajaran merupakan suatu kegiatan belajar mengajar yang dapat disebut sebagai interaksi antara guru dengan siswa dimana pembelajaran merupakan suatu peringkat peristiwa yang mengetahui siswa sedemikian rupa sehingga terjadi proses belajar.

Dimyanti dan Mudjiono (2006) menyatakan "Pembelajaran adalah kegiatan guru secara terprogram dalam desain instruksional, untuk membuat siswa belajar secara aktif, yang menekankan pada penyediaan sumber belajar", Pembelajaran adalah suatu kombinasi yang tersusun meliputi unsur-unsur manusiawi, material, fasilitas, perlengkapan, dan prosedur yang saling mempengaruhi mencapai tujuan pembelajaran.

Pembelajaran suatu pola interaksi antara guru dan siswa yang terorganisasi sedemikian rupa supaya mencapai tujuan atau hasil belajar yang diharapkan. Hal ini sejalan dengan pendapat Reigeluth (1983) yang mengatakan bahwa Instruksional method are the different ways to achieve different outcomes under different conditions. Pernyataan tersebut berarti bahwa metode pembelajaran adalah suatu cara untuk mencapai hasil yang baik pada situasi yang berbeda. Dalam hal ini guru sebagai tenaga perancang pembelajaran (instructional designer) harus mampu memanipulasi situasi, atau keadaan, cara sehingga menjadi suatu suasana yang menarik.
Metode bermain peran digunakan dalam pembelajaran Biologi pada materi Sistem Peredaran darah Manusia dengan tujuan agar siswa memiliki kemampuan; menghayati suatu konsep atau hal yang sebenarnya terjadi dalam realitas, sebagai alat mendiagnosa keadaan, kemampuan dan kebutuhan siswa, pembentukan konsep diri, membina kemampuan siswa dalam memecahkan masalah berpikir kritis, analitis berkomunikasi, hidup dalam kelompok, melatih siswa dalam mengendalikan dan memperbaharui perasaan cara berpikirnya dan perbuatannya. Metode mengajar bermain peran digolongkan ke dalam rumpun teori belajar sosial (Joice et,al, 1992). Teori belajar sosial merupakan perluasan dari teori belajar tradisional. Teori belajar sosial menekankan, bahwa lingkungan-lingkungan yang dihadapkan pada seseorang, tidak random, lingkungan-lingkungan itu kerapkali dipilih dan diubah oleh orang itu melalui perilakunya (Albert Bandura dalam Ratna Wilis Dahar, 1996).

Teknik bermain peran adalah suatu teknik kegiatan belajar yang menekankan pada kemampuan penampilan siswa belajar untuk memerankan suatu status/benda yang terdapat dalam materi sistem peredaran darah. Penggunaan teknik bermain peran dimaksudkan untuk mengenalkan peran-peran dalam konsep peredaran darah kepada siswa belajar, sehingga diharapkan terjadi perubahan sikap (D. Sudjana, 1983). Senada dengan itu, "Role Playing creative drantis, and simulation are teaching that can $\mathrm{b}$ used to bring more reality into the social studies classroom" (Banks, 1985). Berkaitan dengan itu metode pembelajaran bermain peran merupakan suatu pola menerangkan, proses menyebutkan dan menghasilkan situasi, lingkungan yang menyebabkan para siswa berinteraksi, sehingga terjadi perubahan khusus pada tingkah laku mereka Penerapan metode bermain peran sama dengan simulasi. Kedua metode tersebut sangat cocok digunakan pada fase eksplorasi dan ekspansi dan siklus belajar (Sunal dan Haas, 1993).

Menurut Joyce, et.al. (1992) ada empat asumsi yang mendasari bahwa pembelajaran dengan bermain peran kedudukannya sejajar dengan metode-metode mengajar lainnya. Keempat asumsi tersebut sebagai berikut; (1) Secara implisit bermain peran mendukung situasi belajar berdasarkan pengalaman dengan menekankan dimensi disini dan kini sebagai isi 
pengajaran. Dengan metode ini siswa menemukan analogi-analogi mengenai situasi kehidupan. Siswa dapat menampilkan responrespon emosinal secara khas dan sambil belajar dari respon-respon orang lain, (2) Bermain peran memberikan kemungkinan kepada siswa untuk mengungkapkan perasaannya yang tak dapat mereka kenali tanpa bercermin kepada orang lain. Bermain peran dalam konteks proses belajar mengajar memandang bahwa baik diskusi setelah pemesanan maupun pemeranan itu sendiri merupakan aktivitas sentral.(3) Metode ini mengasumsikan bahwa emosi dan ide-ide dapat diangkat ketaraf kesadaran untuk kemudian ditingkatkan mealui proses kelompok. Pemecahan masalah tidak selamanya datang dari orang tertentu (misalnya guru), melainkan dapat saja muncul dari reaksi orng lain terhadap masalah yang tengah diperankan. Dengan demikian, siswa dapar belajar dari pengalaman orang lain tentang memecahkan masalah yang pada gilirannya dapat dimanfaatkan untuk lebih mengembangkan dirinya. Oleh sebab itu mengajar dengan metode bermain peran dapat mengurang peran guru yang terlampau menonjol dalam pengaaran tradisional yang cenderung membuat siswa menjadi pendengar dari pemirsa setia. Metoe mengajar ini mendorong siswa menjadi pendengar untuk turut aktif dalam pemecahan masalah sambil menyimak secara seksama bagaimana orang lain berbicara tentang masalah yang tengah dihadapi, (4) Metode mengajar bermain peran mengasumsikan proses psikologis yang tersembunyi berupa sikap, nilai-nilai, perasaan dan sistem keyakinan dapat diangkat ketingkat kesadaran melalui kombinasi pemeranan secara spontan dan analisisnya. Dengan cara demikian siswa dapat menguji sejauh mana sikapnya relevan dengan sikap orang lain, apakah sikap itu perlu dipertahankan atau diubah. Tanpa orang lain, sulit bagi individu untuk melakukan evaluasi.

Secara umum pembelajaran bermain peran memiliki 9 tahapan yakni; (1) pemanasan (merangsang semangat), (2) memilih peran, (3) memperiapkan pengamat, (4) mempersiapkan tahap-tahap peran, (5) pemeranan, (6) mendiskusikan dan mengevaluasi peran dan isinya, (7) pemeranan ulang, (8) mendiskusikana dan mengevaluasi pemeranan ulang dan, (9) mengkaji manfaatnya melalui saling tukar pengalaman dan penarikan generalisasi (Dahlan, 1990).
Peran (role) dapat diartikan sebagai cara seseorang berperilaku dalam posisi dan situasi tertentu (Gangel,1986). Metode bermain peran adalah suatu cara penguasaan bahanbahan pelajaran melalui pengembangan imajinasi dan penghayatan siswa. Pengembangan imajinasi dan penghayatan dilakukan siswa dengan memerankannya sebagai tokoh hidup atau benda mati.

Menurut Blatner (2002) kelebihan menggunakan metode bermain peran melibatkan seluruh siswa dapat berpartisipasi, mempunyai kesempatan untuk memajukan kemampuannya dalam bekerja sama yaitu: (1) Siswa bebas mengambil keputusan dan berekspresi secara utuh.; (2) Permainan merupakan penemuan yang mudah dan dapat digunakan dalam situasi dan waktu yang berbeda; (3) Guru dapat mengevaluasi pemahaman tiap siswa melalui pengamatan pada waktu melakukan permainan; dan (4) Permainan merupakan pengalaman yang menyenangkan bagi anak.

Didalam kelas suatu masalah diperagakan secara singkat sehingga siswa bisa mengenali tokohnya. Salah satu struktur permainan menurut Gangel (1986) adalah sebagai berikut: (1) Persiapan; pada tahapan ini yang perlu dilakukan adalah menentukan permasalahan, membuat persiapan, menciptakan suasana, pemilihan tokoh/peranan, penjelasan dan pemanasan serta pertimbangan latihan; dan (2) Memainkan; hal -hal yang perlu diperhatikan adalah permainan peran, menghentikan permainan, keterlibatan penonton, menganalisis diskusi, dan melakukan evaluasi. Dan berdasarkan Malcolm, et.al (1980) bermain peran dapat menjadikan para peserta didik memahami, menghayati kejadian yang lebih nyata karena peserta didik melakukan suatu peran secara langsung di lapangan.

Permasalahan yang ada dalam penelitian ini, rumusan masalah secara umum adalah; "apakah hasil belajar siswa pada mata pelajaran biologi akan meningkat pada materi sistem peredaran darah manusia melalui pembelajaran dengan metode bermain peran kelas VIII-1 di SMP Negeri 4 Doloksanggul?".

\section{METODE}

Penelitian dilaksanakan di kelas VIII SMP Negeri 4 Doloksanggul. Penelitian yang dilaksanakan adalah Penelitian Tindakan Kelas (PTK) dengan pertimbangan, guru merupakan 
pihak yang dianggap cukup objektif dalam mengidentifikasi permasalahan pengajaran tetapi kurang pengalaman dalam mencari solusi pemecahannya sehingga dibutuhkan pihak luar untuk melakukan suatu kolaborasi. Di samping itu penelitian tindakan kelas juga memberi kesempatan kepada guru untuk bertindak kreatif dalam praktek pembelajaran sehingga para guru akan melakukan pembaharuan di dalam memecahkan masalah yang ditemui di kelas.

Dalam penelitian tindakan kelas ini peneliti sebagai pelaku utama dalam merancang rencana proses pembelajaran, skenario pembelajaran, bahan ajar yang akan digunakan dan didampingi guru pendamping yang sekaligus juga sebagai kolaborator. Pelaksanaan proses pembelajaran dilaksanakan oleh guru lain (guru mata pelajaran biologi) yang diawali dengan kolaborasi dalam hal bagaimana melaksanakan proses pembelajaran. Proses penelitian ini akan dilaksanakan dalam rangkaian siklus, setiap siklus dilakukan sesuai dengan perubahan yang ingin dicapai.

Lebih rincinya rancangan penelitian tindakan kelas dijabarkan sebagai berikut

1. Perencanaan

Kegiatan yang dilakukan dalam tahapan perencanaan adalah; (1) Menyusun skenario pembelajaran yang sudah disesuaikan dengan metode yang dicanangkan yaitu metode bermain peran; (2) Mempersiapkan materi ajar berdasarkan tema yang dibelajarkan; (3) Membuat lembar observasi; dan (4) Menyusun alat evaluasi untuk mengetahui tingkat keberhasilan hasil belajar dan tingkat kreatifitas siswa.

2. Pelaksanaan Tindakan

Prosedur dan pelaksanaan tindakan penelitian ini menggunakan model kemmis dan Mc. Taggart yang merupakan alur pelaksanaan tindakan yang berlangsung dalam siklus yang di ulang. Siklus yang berulang dilaksanakan apabila target yang telah dicanangkan belum tercapai atau tindakan bersiklus sudah dapat dihentikan jika target yang dicanangkan sudah tercapai atau bahkan sudah terlampaui. Tindakan yang dilakukan adalah tindakan yang sudah disusun melalui adanya scenario pembelajaran dan RPP. Skenario pembelajarannya adalah bermain peran (Role Playing).

3. Observasi

Pada tahap ini dilakukan observasi terhadap proses pelaksanaan tindakan, efek dan hasil tindakan. Observasi dilakukan oleh peneliti dan teman pendamping. Objek yang diamati meliputi aktivitas guru sebagai pengajar dalam menerapkan skenario pembelajaran selama kegiatan pembelajaran berlangsung (termasuk ucapan dan mimik), aktivitas siswa (sikap, respon, pandangan, jalan pikiran, motivasi, ucapan, perilaku dan lain-lain). Observasi dilakukan berdasarkan lembar observasi yang telah disiapkan sebelumnya bagi observer.

4. Refleksi

Hasil yang telah diterima pada tahap observasi dikumpulkan dan dianalisa. Dari hasil observasi dapat merefleksi dengan melihat data observasi, apakah proses belajar mengajar yang diterapkan tersebut dapat meningkatkan hasil belajar biologi. Hasil analisa data yang dilakukan dalam tahap ini akan dipergunakan sebagai acuan untuk merencanakan siklus berikutnya. Hal - hal apa saja yang tidak dapat lagi dilakukan dan hal-hal apa yang akan dilakukan pada siklus berikutnya sebagai solusinya dalam memperbaik proses pembelajaran yang tentunya juga untuk meningkatkan hasil belajar siswa. Bagaimana rancangan penelitian tindakan kelas dapat dilihat pada tabel 1 .

\section{Tabel 1. Prosedur Tindakan}

\section{Tahapan}

S Perencanaan 1. Peneliti bersama guru mitra berelaborasi untuk melakukan

I

$\mathbf{K}$

$\mathbf{L}$

U

S

I analisis kurikulum Ilmu Pengetahuan Alam (IPA) untuk mengetahui kompetensi dasar pada proses pembelajaran dengan mempergunakan metode bermain bermain peran

2. Membuat rencana pembelajaran dengan menerapkan metode bermain peran

3. Merancang skenario pembelajaran dengan menggunakan metode bermain peran

4 Membuat instrumen yang akan digunakan dalam setiap siklus PTK 


\begin{tabular}{|c|c|c|c|}
\hline \multicolumn{4}{|c|}{ 5. Menetapkan indikator ketercapaian } \\
\hline & Tahapan & Uraian & Hasil \\
\hline $\begin{array}{l}\text { S } \\
\mathbf{I} \\
\text { K } \\
\mathbf{L} \\
\mathbf{U} \\
\text { S }\end{array}$ & Tindakan & $\begin{array}{l}\text { 1. Hasil analisis kurikulum yang telah dilakukan selanjutnya } \\
\text { diimplementasikan pada siswa mengenai bermain peran. } \\
\text { 2. Mendeskripsikan materi pelajaran dengan skenario } \\
\text { bermain peran yang telah dirancang. } \\
\text { 3. Pembagian kelompok yang disesuaikan dengan jumlah } \\
\text { siswa pada kelas perlakuan tindakan. } \\
\text { 4. Setiap kelompok diberikan waktu untuk mendiskusikan } \\
\text { skenario bermain peran yang telah dirancang guru dan } \\
\text { peneliti. } \\
\text { 5. Setiap kelompok mempresentasikan hasil diskusi } \\
\text { mereka. } \\
\text { 6. Materi pelajaran disampaikan dengan menggunakan } \\
\text { skenario pembelajaran yang sudah dirancang. } \\
\text { 7. Siswa diberi kesempatan untuk bertanya kepada guru } \\
\text { mengenai materi yang belum dipahami. } \\
\text { 8. Guru bersama dengan siswa menarik kesimpulan terhadap } \\
\text { materi yang disajikan dengan metode bermain peran. } \\
\text { 9. Di akhir tindakan, guru memberikan kuis yang berkaitan } \\
\text { dengan materi/indikator yang telah diberikan. } \\
\text { 10. Jenis data yang dikumpulkan berupa, hasil tes/kuis, dan } \\
\text { perilaku siswa dalam bermain peran. }\end{array}$ & $\begin{array}{l}\text { Hasil } \\
\text { kemampuan } \\
\text { siswa dalam } \\
\text { memahami } \\
\text { materi } \\
\text { pembelajaran } \\
\text { melalui kuis. }\end{array}$ \\
\hline & Tahapan & Uraian & Hasil \\
\hline & Observasi & $\begin{array}{l}\text { 1. Kegiatan belajar mengajar. } \\
\text { 2. Keaktifan siswa dalam menyampaikan hasil kerja. } \\
\text { 3. Keaktifan siswa dalam proses bermain peran. } \\
\text { 4. Kemampuan siswa dalam melakukan peran yang } \\
\text { ditugaskan. } \\
\text { 5. Kemampuan siswa dalam melakukan modifikasi teks } \\
\text { skenario dalam bermain peran. }\end{array}$ & $\begin{array}{lr}\text { Data } & \text { yang } \\
\text { akan } & \text { di } \\
\text { analisis } & \end{array}$ \\
\hline & Refleksi & $\begin{array}{l}\text { Peneliti dengan guru mitra melaksanakan evaluasi } \\
\text { terhadap proses belajar mengajar dengan menggunakan } \\
\text { metode bermain peran. Apabila pada siklus ini hasil } \\
\text { pembelajaran tidak mencapi indikator keberhasilan } \\
\text { penelitian maka tindakan penelitian ini dilanjutkan pada } \\
\text { siklus kedua dengan prosedur penelitian yang sama. }\end{array}$ & $\begin{array}{l}\text { Skenario } \\
\text { pembelajaran } \\
\text { yang sudah } \\
\text { diperbaiki. }\end{array}$ \\
\hline
\end{tabular}

\section{Teknik Analisis Data}

Tahapan sesudah pengumpulan data selanjutnya diikuti dengan analisis data. Data yang dianalisis adalah data kualitatif untuk melihat perkembangan yang diperoleh dari hasil observasi keaktifan siswa dan hasil belajar siswa selama proses pembelajaran dan setelah proses pembelajaran yang menggunakan metode bermain peran. Analisis data yang dilakukan secara kualitatif merujuk kepada Miles dan Huberman (1992) sebagai berikut: (1) reduksi data, dalam hal ini peneliti data yang relevan, penting dan berguna untuk menjelaskan tentang apa yang menjadi sasaran analisis, (2) sajian deskriptif tentang apa yang ditemukan dalam analisis, yang disajikan dalam bentuk narasi dan persentase dan, (3) verifikasi 160 atau penarikan kesimpulan. Verifikasi data dapat dilakukan dengan cara:

1) Credibility: yaitu usaha untuk membuat lebih terpercaya baik proses, interpretasi dan temuan dalam penelitian ini yaitu dengan cara: (a) keterkaitan penelitian lama dengan yang diteliti yaitu dilaksanakan dengan tidak tergesa-gesa sehingga pengumpulan data dan informasi diperoleh secara sempurna, (b) ketekunan pengamatan terhadap aktivitas peserta didik sebagai informasi penelitian untuk memperoleh informasi yang sahih, (c) melakukan triangulasi: yaitu informasi yang diperoleh dari berbagai sumber diperiksa ulang antara peneliti, guru mitra, (d) mendiskusikan dengan dosen pembimbing 
dan teman sejawat, sehingga penelitian akan mendapatkan masukan dari orang lain,

2) Tranferability: yaitu pembaca laporan penelitian ini diharapkan mendapat gambaran yang jelas mengenai situasi bagaimana agar hasil penelitian dapat diimplementasikan kepada situasi lain yang sejenis dalam rangka pemecahan masalah proses pembelajaran.

3) Dependability: yaitu peneliti mengusahakan konsistensi dalam keseluruhan konsistensi dalam keseluruhan proses penelitian dengan memperhatikan semua aktivitas peneliti harus ditinjau ulang terhadap data yang telah diperoleh (bersiklus) dan dapat dipertanggungjawabkan.

4) Confirmability: yaitu data harus dipastikan keterpercayaannya (objetivitas) sehingga kualitas data dapat dipertanggungjawabkan.

Teknik pemeriksaan data lainnya yang digunakan dalam penelitian ini adlah audit trail, hal ini dimaksudkan agar seluruh proses penelitian yang dilaksanakan tepat dan akurat. Audit artinya pemeriksaan terhadap ketelitian penelitian yang dilakukan, sehingga timbul keyakinan bahwa apa yang dilaporkan itu apa adanya, sedangkan trail artinya jejak yang dapat dilacak dan ditelusuri. Auditing dilaksanakan terhadap proses kegiatan pembelajaran bukan berdasarkan pada hasil dari suatu kegiatan tersebut. Dalam hal ini Moleong (2002) menyatakan bahwa proses auditing dilaksanakan melalui empat tahap yaitu: praentry, penetapan yang dapat diaudit, kesepakatan formal dan penentuan keabsahan data.

Praentry, adalah tahapan yang dilakukan dengan melakukan pertemuan dengan dosen pembimbing untuk melakukan auditing, peneliti sebagai auditing menyampaikan penjelasan kepada auditor mengenai maksud, proses da hasil penemuan penelitian. Peneliti juga menjelaskan bagaimana proses penelitian yang telah dilakukan dan teknik yang dipergunakan untuk mendapatkan informasi yang diperlukan peneliti.

Penetapan yang dapat diaudit adalah tahapan peneliti menyerahkan semua catatan pelaksanaan proses hasil penelitian. Hasil penelitian dipelajari auditor, selanjutnya auditor meminta penjelasan kepada peneliti mengenai hal-hal yang kurang dipahami. Setelah proses auditing selesai dikerjakan, selanjutnya auditor menetapkan kesimpulan tentang penelitian apakah dapat dilanjutkan, dihentikan sementara atau dihentikan sama sekali.

Kesepakan formal, tahapan resmi antara peneliti dengan auditor. Dalam tahap ini disebut persetujuan resmi tentang hasil temuan yang telah dicapai auditor. Persetujuan yang dibuat meliputi: batas waktu pelaksanaan, tujuan pelaksanaan audit, penjabaran peranan yang telah dilakukan, penetapan format yang dibutuhkan, serta kriteria yang dibutuhkan, perundingan kembali jika diperlukan misalnya apa yang harus dilakukan apabila terjadi kesalahan.

Penentuan keabsahan data, merupakan tahapan penting dalam kegiatan auditing. Pada tahapan ini kegiatan yang dilakukan meliputi pemeriksaan terhadap kepastian maupun terhadap ketergantungan. Pemeriksaan terhadap kriteria kepastian ini dengan langkah antara lain, auditor akan memastikan apakah hasil penemuan benar berasal dari data. Auditor akan melakukan penelitian terhadap derajat ketelitian peneliti dengan melihat ada tidaknya penyimpangan, memperhatikan terminalogy penelitian apakah didasarkan pada teori. Selanjutnya auditor akan menelaah kegiatan peneliti dalam melaksanakan pemeriksaan keabsahan data dengan melihat bagaimana peneliti menggunakan triangulasi, analisis kasus negatif. Dengan teknik auditing ini, maka seluruh bahan dalam penelitian ini akan disiapkan agar dapat diperiksa oleh pembimbing. Setelah auditing selesai maka pembimbing akan memberikan umpan balik kepada peneliti mengenai hasil dari kegiatan auditing itu sendiri.

\section{Indikator Keberhasilan Tindakan}

Indikator yang digunakan sebagai ukuran keberhasilan terhadap tindakan yang dilakukan dalam satu siklus penelitian menggunakan dua indikator yaitu: (1) Yang digunakan untuk menunjukkan keberhasilan proses pembelajaran adalah suksesnya guru dalam melaksanakan rencana tindakan. Rencana tindakan dikatakan mudah dilaksanakan apabila prosedur guru selama mengajar berjalan dengan lancar. Guru tidak mempunyai problem yang serius berkaitan dengan fasilitas, materi dan prosedur. Selain itu guru juga merasa senang dan antusia mengajar dengan menggunakan rencana pembelajaran tersebut. Suksesnya siswa dalam mengikuti kegiatan pembelajaran, mudah tidaknya siswa memahami materi melalui pendekatan 
pembelajaran bermain peran yang digunakan guru tersebut; (2) Yang digunakan untuk menunjukkan suksesnya proses mengajar adalah hasil belajar siswa. Rencana tindakan dikatakan sukses atau efektif untuk meningkatkan kemampuan peserta didik apabila; peserta didik dapat memunculkan respon-respon yang diharapkan setelah berlangsungnya kegiatan pembelajaran dan rata-rata skor tes peserta didik $>65$ dan yang memperoleh skor $>65$ paling sedikit harus $65 \%$ peserta didik. Hal ini mengacu pada Kriteria Ketuntasan Minimal (KKM) SMP Negeri 4 Doloksanggul mata pelajaran IPA

\section{HASIL PENELITIAN}

Proses pembelajaran pada pertemuan selanjutnya (siklus pertama pertemuan kedua), peserta didik diminta oleh guru untuk melakukan bermain peran sesuai dengan yang dibagikan guru pada hari sebelumnya yang tentunya dengan panduan dari guru. Dari bermain peran yang dilakukan pada umumnya peserta didik hanya menghafal teks saja tanpa dapat memahami konsep dari materi yang diperankannya. Dari 15 peserta didik yang mendapat peran, hanya 3 orang $(10,34 \%)$ peserta didik yang mampu memodifikasi skenario yang di rancang oleh guru, yaitu; Martha Lusiana Pane, Rebeka Sihite dan Roba Aditya Silitonga. Di akhir pembelajaran pada siklus pertama pertemuan kedua dilaksanakan post tes yang hasilnya menunjukkan hanya 8 peserta didik yang tuntas atau sekitar 27,6\%. Tuntas yang dimaksud adalah nilai melebihi atau sama dengan 65. Nilai peserta didik dapat diihat pada tabel 2 .

Tabel 2 Daftar Nilai peserta didik pada postes siklus -I

\begin{tabular}{|c|c|c|c|c|c|c|}
\hline No & Nama Peserta Didik & Benar & Salah & Kosong & Skor & Keterangan \\
\hline 1 & ABM & 15 & 3 & 2 & $\mathbf{7 5}$ & Tuntas \\
\hline 2 & AMS & 5 & 14 & 1 & 25 & Tidak tuntas \\
\hline 3 & DRS & 3 & 16 & 1 & 15 & Tidak tuntas \\
\hline 4 & ERS & 12 & 8 & 0 & 60 & Tidak tuntas \\
\hline 5 & EKP & 13 & 7 & 0 & $\mathbf{6 5}$ & Tuntas \\
\hline 6 & EBS & 13 & 7 & 0 & $\mathbf{6 5}$ & Tuntas \\
\hline 7 & FOL & 6 & 13 & 1 & 30 & Tidak tuntas \\
\hline 8 & FNS & 1 & 15 & 4 & 5 & Tidak tuntas \\
\hline 9 & HAS & 11 & 9 & 0 & 55 & Tidak tuntas \\
\hline 10 & JKP & 12 & 8 & 0 & 60 & Tidak tuntas \\
\hline 11 & JFP & 6 & 13 & 1 & 30 & Tidak tuntas \\
\hline 12 & JSA & 8 & 12 & 0 & 40 & Tidak tuntas \\
\hline 13 & JPA & 2 & 4 & 14 & 10 & Tidak tuntas \\
\hline 14 & LSA & 6 & 8 & 6 & 30 & Tidak tuntas \\
\hline 15 & LSG & 14 & 6 & 0 & $\mathbf{7 0}$ & Tuntas \\
\hline 16 & MMU & 7 & 13 & 0 & 35 & Tidak tuntas \\
\hline 17 & MLP & 12 & 7 & 1 & 60 & Tidak tuntas \\
\hline 18 & MSP & 8 & 12 & 0 & 40 & Tidak tuntas \\
\hline 19 & QSA & 10 & 4 & 6 & 50 & Tidak tuntas \\
\hline 20 & RSG & 10 & 8 & 2 & 50 & Tidak tuntas \\
\hline 21 & RSE & 15 & 5 & 0 & $\mathbf{7 5}$ & Tuntas \\
\hline 22 & RSA & 8 & 12 & 0 & 40 & Tidak tuntas \\
\hline 23 & RPA & 15 & 1 & 4 & $\mathbf{7 5}$ & Tuntas \\
\hline 24 & RAG & 7 & 11 & 2 & 35 & Tidak tuntas \\
\hline 25 & RBS & 10 & 10 & 9 & 50 & Tidak tuntas \\
\hline 26 & RAS & 13 & 7 & 0 & $\mathbf{6 5}$ & Tuntas \\
\hline 27 & RPS & 1 & 10 & 9 & 5 & Tidak tuntas \\
\hline 28 & SPB & 13 & 7 & 0 & $\mathbf{6 5}$ & Tuntas \\
\hline 29 & YRP & & & & & \\
\hline
\end{tabular}




\section{Refleksi dan Perbaikan untuk Siklus II}

Berdasarkan hasil nilai tes dan hasil observasi tentang aktivitas belajar siswa, maka dilakukan penelaahan yang lebih teliti untuk menentukan tindakan apa yang boleh diteruskan pada siklus kedua dan tindakan apa yang harus diperbaiki. Hal- hal yang dapat diteruskan pada siklus kedua adalah penyampaian materi yang akan dipelajari pada pertemuan selanjutnya, penyampaian tujuan pembelajaran. Demikian juga pemberian kesempatan dan waktu yang lebih banyak untuk melakukan pencarian informasi/ tinjauan literatur dari buku BSE (Buku Sekolah Elektronik) tentang skema pembekuan darah dan teknik mengidentifikasi golongan darah seseorang pada klasifikasi golongan darah sistem "ABO".

Hal - hal yang perlu diperbaiki dari siklus pertama adalah penggunaan waktu yang lebih efesien, memberikan waktu yang lebih kepada peserta didik dalam melakukan tinjauan literatur untuk mencari informasi tentang skema pembekuan darah dan teknik identifikasi golongan darah dan kalau memungkinkan waktu hendaknya semua peserta didik mendapat peran pada pertemuan selanjutnya. Pada siklus sebelumnya jumlah siswa yang memerankan tokoh dalam sistem peredaran darah manusia sedikit. Pembelajaran harus dimulai dari pemberian informasi yang lebih mendetail agar siswa dapat terbantu untuk melakukan tinjauan literatur. Untuk mempertinggi penguatan ingatan dapat dilakukan penyusunan ulang ringkasan.

Untuk meningkatkan aktivitas peserta didik dan keberaniannya mengemukakan pendapat guru harus sesering mungkin melakukan dialog dengan peserta didik sehingga kesenjangan komunikasi antara guru dan siswa perlahan-lahan dapat diatasi. Dan pada saat peserta didik akan menyampaikan hasil kerja tinjauan literatur dihunjuk langsung agar lebih memotivasi dan memberikan tanggungjawab secara personal. Apabila tidak melakukan tugas diberi sangsi berupa pemberian tugas yang lebih untuk dikerjakan dirumah. Hal ini perlu dilakukan untuk menumbuhkan rasa tanggung jawab secara personal.

\section{Pelaksanaan dan Hasil Penelitian pada Siklus II \\ Penyusunan Rencana Tindakan}

Pada pertemuan ketiga siklus II di kelas dilakukan pretes untuk mengukur kemampauan awal peserta didik terutama penguasaan terhadap pengetahuan tentang skema proses pembekuan darah dan teknik identifikasi golongan darah manusia yang akan diajarkan. Jumlah peserta didik yang mengikuti ada sebanyak 29 orang. Hasil dari perolehan skor yang diperoleh peserta didik pada pretes dapat dilhat pada Tabel 3.

Tabel .3. Data Perolehan Peserta didik pada Pretes siklus II

\begin{tabular}{ccccccc}
\hline No & Nama Peserta Didik & Benar & Salah & Kosong & Skor & Keterangan \\
\hline $\mathbf{1}$ & ABM & 6 & 4 & 5 & 39,6 & Tidak tuntas \\
\hline $\mathbf{2}$ & AMS & 4 & 7 & 4 & 26,4 & Tidak tuntas \\
\hline $\mathbf{3}$ & DRS & 2 & 13 & 0 & 13,2 & Tidak tuntas \\
\hline $\mathbf{4}$ & ERS & 7 & 5 & 3 & 46,2 & Tidak tuntas \\
\hline $\mathbf{5}$ & EKP & 6 & 6 & 3 & 39,6 & Tidak tuntas \\
\hline $\mathbf{6}$ & EBS & 5 & 5 & 5 & 33,0 & Tidak tuntas \\
\hline $\mathbf{7}$ & FOL & 4 & 6 & 5 & 26,4 & Tidak tuntas \\
\hline $\mathbf{8}$ & FNS & 3 & 9 & 3 & 19,8 & Tidak tuntas \\
\hline $\mathbf{9}$ & HAS & 6 & 5 & 4 & 39,6 & Tidak tuntas \\
\hline $\mathbf{1 0}$ & JKP & 5 & 10 & 0 & 33,0 & Tidak tuntas \\
\hline $\mathbf{1 1}$ & JFP & 6 & 9 & 0 & 39,6 & Tidak tuntas \\
\hline $\mathbf{1 2}$ & JSA & 4 & 7 & 4 & 26,4 & Tidak tuntas \\
\hline $\mathbf{1 3}$ & JPA & 3 & 10 & 2 & 19,8 & Tidak tuntas \\
\hline $\mathbf{1 4}$ & LSA & 3 & 8 & 4 & 19,8 & Tidak tuntas \\
\hline $\mathbf{1 5}$ & LSG & 5 & 7 & 3 & 33,0 & Tidak tuntas \\
\hline $\mathbf{1 6}$ & MMU & 7 & 8 & 0 & 46,2 & Tidak tuntas \\
\hline $\mathbf{1 7}$ & MLP & 7 & 8 & 0 & 46,2 & Tidak tuntas \\
\hline $\mathbf{1 8}$ & MSP & 7 & 7 & 1 & 46,2 & Tidak tuntas \\
\hline $\mathbf{1 9}$ & QSA & 6 & 9 & 0 & 39,6 & Tidak tuntas \\
\hline
\end{tabular}




\begin{tabular}{llccccc}
\hline $\mathbf{2 0}$ & RSG & 4 & 9 & 2 & 26,4 & Tidak tuntas \\
\hline $\mathbf{2 1}$ & RSE & 7 & 9 & 0 & 46,2 & Tidak tuntas \\
\hline $\mathbf{2 2}$ & RSA & 4 & 11 & 0 & 26,4 & Tidak tuntas \\
\hline $\mathbf{2 3}$ & RPA & 6 & 7 & 2 & 39,6 & Tidak tuntas \\
\hline $\mathbf{2 4}$ & RAG & 5 & 9 & 1 & 33,0 & Tidak tuntas \\
\hline $\mathbf{2 5}$ & RBS & 5 & 8 & 2 & 33,0 & Tidak tuntas \\
\hline $\mathbf{2 6}$ & RAS & 6 & 9 & 0 & 39,6 & Tidak tuntas \\
\hline $\mathbf{2 7}$ & RPS & 2 & 12 & 1 & 13,2 & Tidak tuntas \\
\hline $\mathbf{2 8}$ & SPB & 2 & 13 & 0 & 13,2 & Tidak tuntas \\
\hline $\mathbf{2 9}$ & YRP & $\mathbf{4}$ & $\mathbf{9}$ & $\mathbf{2}$ & $\mathbf{2 6 , 4}$ & Tidak tuntas \\
\hline
\end{tabular}

Perencanaan pada siklus kedua hampir sama seperti pada siklus pertama, pembelajaran yang diberikan kepada siswa adalah konsep skema pembekuan darah jika terjadi luka pada tubuh. Materi disajikan dalam bentuk bermain peran yang diawali dengan ceramah dan tinjauan literatur. Dari hasil refleksi pada siklus pertama maka penyusunan Silabus dan Rencana Pelaksanaan Pembelajaran disesuaikan dengan mempertimbangkan hal-hal yang akan diteruskan dan hal-hal yang harus diperbaiki. Rencana Pelaksanaan Pembelajaran yang akan diterapkan pada siklus kedua dapat dilihat pada lampiran.

Pengisian lembar observasi aktivitas peserta didik selama proses pembelajaran lebih objektif. Selanjutnya dilakukan pertemuan dengan kolaborator untuk mempertajam pengamatan terhadap hal-hal yang perlu dikembangkan untuk peningkatan kualitas pembelajaran siswa dan hal-hal apa yang nantinya harus dihilangkan. Cara guru dalam menyampaikan pertanyaan kepada peserta didik agar meminta salah satu peserta didik, agar suasana belajar tidak menjadi gaduh, karena pada pertemuan sebelumnya peserta didik menjawab atau menyambung kalimat guru yang tidak lengkap/tidak tuntas secara beramairamai.

Kegiatan pembelajaran siklus kedua pertemuan pertama ini dimulai dengan materi skema pembekuan darah jika terjadi luka. Penjelasan terlebih dahulu disampaikan oleh guru, dan diusahakan mengajukan pertanyaan sesering mungkin. Dengan demikian mungkin peserta didik akan lebih memiliki keberanian dalam mengungkapkan pendapatnya. Selanjutnya, menyampaikan materi tentang teknik mengidentifikasi darah manusia. Jika perlu nantinya penyampaian konsep teknik identifikasi golongan darah dilakukan dengan metode simulasi/ peragaan didepan kelas. Metode simulasi dengan mempergunakan kartu identitas golongaan darah dan jenis-jenis antigen dan antibodi yang terkandung di dalam setiap golongan darah, serta kartu pengambil kesimpulan. Pada pelaksanaan pembelajaran guru lebih banyak berperan untuk menciptakan suasana belajar saja, sedangkan kegiatan pembelajaran lebih banyak dilaksanakan oleh siswa.

\section{Pelaksanaan Tindakan dan Hasil Observasi.}

Penerapan pembelajaran pada siklus kedua ini dilakukan sesuai dengan Rencana Pelaksanaan Pembelajaran yang telah dirancang pada tahap perencanaan siklus kedua. Observasi dilakukan oleh kolaborator selama tindakan dilakukan. Penyampaian materi dibagi dalam dua sub yaitu materi tentang skema pembekuan darah dan teknik untuk mengidentifikasi golongan darah. Diakhir tindakan dilakukan evaluasi baik terhadap hasil belajar peserta didik maupun hasil observasi dan catatancatatan khusus selama pembelajaran berlangsung dari peneliti dan kolaborator.

Pada pembelajaran siklus kedua pertemuan pertama, dari data yang diperoleh terhadap keaktivan peserta didik diperoleh data sebagai berikut: yang mempunyai keberanian untuk mempresentasikan hasil kerja tinjauan literaturnya hanya satu orang $(3,45 \%)$ saja, yang termasuk mampu melakukan tinjauan literatur ada 6 orang $(20,68 \%)$, yang mengajukan pertanyaan ada sebanayk 3 orang $(10,34 \%)$ dan yang menjawab pertanyaan guru ada 2 orang $(6,90 \%)$.

Dari hasil observasi terlihat jelas bahwa aktivitas peserta didik pada keberanian untuk mempresentasikan hasil tinjauan pustaka tidak mengalami peningkatan, sama seperti pada siklus yang pertama hanya pelakunya yang berganti. Pada kriteria kemampuan melakukan tinjauan pustaka terjadi malah penurunan dari $24,14 \%$ menjadi $20,68 \%$. Untuk jumlah siswa yang mengajukan pertanyaan mengalami 
peningkatan, di siklus pertama jumlah siswa yang bertanya hanya ada dua peserta sementara pada siklus kedua ada sebanyak 3 orang. Pada keberanian untuk mengungkapkan pendapat atas pertanyaan guru terjadi penurunan, pada siklus pertama ada 4 peserta yang mengajukan pendapat sementara di siklus kedua yang mengajukan pendapatnya hanya ada 2 orang saja.

Hasil wawancara yang dilakukan terhadap peserta didik yang menunjukkan aktivitas rendah, mereka menyatakan sulit untuk berbicara di depan kelas sehingga tidak berani mempresentasikan hasil tinjauan literaturnya. Banyak yang merasa sungkan untuk bertanya atau menjawab pertanyaan guru. Disamping itu, dari tes akhir yang dilakukan terhadap peserta didik pada akhir siklus kedua ini diperoleh hasil $65,52 \%$ dari jumlah peserta didik mendapat perolehan nilai 65 keatas. Untuk jelas dapat dilihat nilai skor perolehan peserta didik pada tabel 4 .

Tabel 4. Nilai skor Perolehan Peserta didik Siklus II

\begin{tabular}{ccccccc}
\hline No & Nama Peserta Didik & Benar & Salah & Kosong & Skor & Keterangan \\
\hline $\mathbf{1}$ & ABM & 14 & 1 & 0 & $\mathbf{9 2 , 4 0}$ & Tuntas \\
\hline $\mathbf{2}$ & AMS & 8 & 7 & 0 & 52,80 & Tidak Tuntas \\
\hline $\mathbf{3}$ & DRS & 9 & 6 & 0 & 59,40 & Tidak Tuntas \\
\hline $\mathbf{4}$ & ERS & 12 & 3 & 0 & $\mathbf{7 9 , 2 0}$ & Tuntas \\
\hline $\mathbf{5}$ & EKP & 8 & 7 & 0 & 52,80 & Tidak Tuntas \\
\hline $\mathbf{6}$ & EBS & 13 & 2 & 0 & $\mathbf{8 5 , 8 0}$ & Tuntas \\
\hline $\mathbf{7}$ & FOL & 10 & 5 & 0 & $\mathbf{6 6 , 6 0}$ & Tuntas \\
\hline $\mathbf{8}$ & FNS & 8 & 7 & 0 & 52,80 & Tidak Tuntas \\
\hline $\mathbf{9}$ & HAS & 12 & 3 & 0 & $\mathbf{7 9 , 2 0}$ & Tuntas \\
\hline $\mathbf{1 0}$ & JKP & 12 & 3 & 0 & $\mathbf{7 9 , 2 0}$ & Tuntas \\
\hline $\mathbf{1 1}$ & JFP & 11 & 4 & 0 & $\mathbf{7 2 , 6 0}$ & Tuntas \\
\hline $\mathbf{1 2}$ & JSA & 11 & 4 & 0 & $\mathbf{7 2 , 6 0}$ & Tuntas \\
\hline $\mathbf{1 3}$ & JPA & 10 & 5 & 0 & $\mathbf{6 6 , 6 0}$ & Tuntas \\
\hline $\mathbf{1 4}$ & LSA & 13 & 2 & 0 & $\mathbf{8 5 , 8 0}$ & Tuntas \\
\hline $\mathbf{1 5}$ & LSG & 7 & 8 & 0 & 46,20 & Tidak Tuntas \\
\hline $\mathbf{1 6}$ & MMU & 7 & 8 & 0 & 46,20 & Tidak Tuntas \\
\hline $\mathbf{1 7}$ & MLP & 13 & 2 & 0 & $\mathbf{8 5 , 8 0}$ & Tuntas \\
\hline $\mathbf{1 8}$ & MSP & 10 & 5 & 0 & $\mathbf{6 6 , 6 0}$ & Tuntas \\
\hline $\mathbf{1 9}$ & QSA & 8 & 7 & 0 & 52,80 & Tidak Tuntas \\
\hline $\mathbf{2 0}$ & RSG & 6 & 9 & 0 & 39,60 & Tidak Tuntas \\
\hline $\mathbf{2 1}$ & RSE & 14 & 1 & 0 & $\mathbf{9 2 , 4 0}$ & Tuntas \\
\hline $\mathbf{2 2}$ & RSA & 10 & 5 & 0 & $\mathbf{6 6 , 6 0}$ & Tuntas \\
\hline $\mathbf{2 3}$ & RPA & 14 & 1 & 0 & $\mathbf{9 2 , 4 0}$ & Tuntas \\
\hline $\mathbf{2 4}$ & RAG & 7 & 8 & 0 & 46,20 & Tidak Tuntas \\
\hline $\mathbf{2 5}$ & RBS & 12 & 3 & 0 & $\mathbf{7 9 , 2 0}$ & Tuntas \\
\hline $\mathbf{2 6}$ & RAS & 14 & 1 & 0 & $\mathbf{9 2 , 4 0}$ & Tuntas \\
\hline $\mathbf{2 7}$ & RPS & 7 & 8 & 0 & 46,20 & Tidak Tuntas \\
\hline $\mathbf{2 8}$ & SPB & 10 & 5 & 0 & $\mathbf{6 6 , 6 0}$ & Tuntas \\
\hline $\mathbf{2 9}$ & YRP & $\mathbf{1 3}$ & $\mathbf{2}$ & $\mathbf{0}$ & $\mathbf{8 5 , 8 0}$ & Tuntas \\
\hline & & & & & & \\
\hline & & & & & & \\
\hline
\end{tabular}

\section{PEMBAHASAN}

Dari data tes hasil belajar menunjukkan bahwa indikator penelitian sudah dapat dibuktikan baik dari rata-rata perolehan nilai peserta didik pada siklus kedua. Data tes akhir pada siklus dan siklus kedua peningkatan hasil belajar siswa sudah melampau target yang sudah dicanangkan. Oleh karena itu penelitian tindakan kelas ini dihentikan sampai pada siklus kedua ini. Selanjutnya, tindakan yang sudah diterapkan guru pada siklus pertama dan kedua dapat diteruskan pada pembelajaran dengan materi yang lain.

Namun, dari data itu masih terdapat $34,48 \%$ lagi diantara peserta didik yang hasil belajarnya belum mencapai target. Dari 29 peserta didik di kelas, ada 19 peserta didik yang sudah mencapai target yang dicanangkan sedangkan 10 peserta didik lagi masih belum mencapai target. Dari 10 orang peserta didik 
yang tidak tuntas terdapat 3 orang peserta didik yang mengalami penurunan hasil belajar dari siklus pertama ke siklus kedua. Ketiga orang tersebut adalah atas nama Ernita Katarina Purba, Larisma Situmorang, dan Rahmi Safitri Gaja. Nilai Hasil Belajar yang diperoleh Ernita Katarina Purba pada siklus pertama adalah 65,00 dan pada siklus kedua adalah 52,80.

Nilai Hasil Belajar yang diperoleh Larisma Situmoranng pada siklus pertama adalah 70 dan pada siklus kedua adalah 46,20 dan nilai Hasil Belajar yang diperoleh Rahmi Safitri Gaja pada siklus pertama adalah 50 dan pada siklus kedua adalah 39,60. Data hasil observasi aktivitas belajar dan hasil belajar peserta didik ini menunjukkan bahwa tindakan yang dilakukan pada kegiatan pembelajaran belum sesuai untuk keseluruhan peserta didik. Artinya masih ada tindakan-tindakan lain yang harus diberikan kepada peserta didik tersebut untuk meningkatkan hasil belajar dan aktivitas belajarnya. Namun demikian tidak berarti pembelajaran bermain peran tidak sesuai digunakan untuk meningkatkan hasil belajar dan aktivitas belajar mereka, karena pembelajaran bermain peran terbuka terhadap penggunaan berbagai strategi pembelajaran yang dapat dipadukan dengannya sesuai dengan keadaan peserta didik.

\section{PENUTUP}

Penelitian tindakan kelas ini dilakukan di kelas VIII-1 SMP negeri 4 Doloksanggul untuk mata pelajaran biologi semester tiga. Dari penelitian dapat disimpulkan sebagai berikut:

1. Jumlah peserta didik yang tuntas pada siklus pertama submateri komponen-komponen darah dan struktur jantung ada sebanyak 8 orang atau sebesar $27,6 \%$.

2. Jumlah peserta didik yang tuntas pada siklus kedua submateri skema pembekuan darah manusia dan teknik identifikasi golongan darah ada sebanyak 19 orang atau sebesar $65,52 \%$.

3. Terjadi peningkatan hasil belajar peserta didik pada materi sistem peredaran darah manusia kelas VIII - $_{1}$ di SMP Negeri 4 Doloksanggul dari siklus pertama ke siklus kedua sebesar $37,92 \%$.

\section{DAFTAR PUSTAKA}

Banks, James.A. (1985). Teaching Strategis For the Social Studies. New York: Longman Inc.

Carin, A.A. \& Sund, R.B. (1989). Teaching Science Through Discovery. Colombus. Ohio: Meril Publishing Company.

Dahar, Ratna. (1996). Teori-Teori Belajar. Bandung: Gelora aksara pratama.

Sudjana, D. (1983). Metode dan Teknik Kegiatan Belajar Parsisipatif. Bandung: Thema 76.

Dimyanti dan Mudjiono, (2006). Belajar dan Pembelajaran. Jakarta: Rineka Cipta.

Hasruddin. (2006). Strategi Pembelajaran Kooperatif Pada Pembelajaran Biologi. TABULARASA Jurnal Pendidikan PPS Unimed. Volume:03 (01): 14-18 Desember 2006.

Joyce, B. et al. (1992). Models of Teaching. Boston: Allyn and Bacon A Division of Simon \& Schuster. Inc

Kemmis, S \& McTaggart, R. (1992). The Action Research Planner. Victoria: Deakin University.

Malcolm, E. (1980). Role Playing A Practical Manual For Facilatarators. Evenue. California University.

Nasution, S. (2003) Metode Pnelitian Naturalistik Kualitatif. Bandung: Tarsito.

Prihantoro, L., Wirasasmita, O., dan Liliasari. (1986). IPA terpadu. Jakarta: Depdikbud Universitas terbuka.

Reigeluth, M.., Charles. (1983). Instructional Design Theories And Models: an Overview of Their Current Status. Hillsdale, New Jersey.

Sunal, C.S. \& Haas, M.E. (1993). Sosical Studies and The Elementtary Middle School Student. New York: H.H Rinehart and Winston, Inc

Suyitno. (1995) Karakteristik IPA dan Konsekuensi Pembelajaran bagi Siswa. Cakrawala Pendidikan, Vol. 2 p. 25

Trianto, (2010). Model Pembelajaran Terpadu. Jakarta: Bumi Aksara. 